\title{
RELEVANCE OF THE TECHNOLOGY ACCEPTANCE MODEL (TAM) IN INFORMATION MANAGEMENT RESEARCH: A REVIEW OF SELECTED EMPIRICAL EVIDENCE
}

\author{
DOI: 10.17261/Pressacademia.2020.1186 \\ RJBM-V.7-ISS.1-2020(4)-p.34-44
}

\author{
Mustapha Osman Opoku ${ }^{1}$, Francis Enu-Kwesi ${ }^{2}$ \\ ${ }^{1}$ Catholic University, College of Ghana, Faculty of Economics and Business Administration, Fiapre, Ghana. \\ yawosman2004@yahoo.co.uk, ORCID: 0000-0001-6314-1976 \\ 2University of Cape Coast, Institute for Development Studies, Ghana. \\ fenu-kwesi@ucc.edu.gh,ORCID: 0000-0003-0965-541X
}

Date Received: November 18, 2019

Date Accepted: February 21, 2020

\section{To cite this document}

Opoku, M.O., F. Enu-Kwesi, (2019). Relevance of the technology acceptance model (TAM) in information management research: a review of selected empirical evidence. Research Journal of Business and Management (RJBM), V.7(1), p.34-44.

Permemant link to this document: http://doi.org/10.17261/Pressacademia.2020.1186

Copyright: Published by PressAcademia and limited licenced re-use rights only.

\begin{abstract}
Purpose- The purpose of the study was to examine the relevance of the Technology Acceptance Model (TAM) in information management research, and how it has been extended in relation to its perceived usefulness and perceived ease of use.

Methodology- A desk study approach was used to review some of the studies that have used the model. Search engines, such as google scholar, yahoo search, and answers. com, were used to search through internationally renowned journals like Emerald, Science direct, IJRIC, South African Journal of Information Management and others. In all, twenty two (22) articles that were published from 1999 to 2016 were used. The 22 articles were those which have used the TAM in empirical studies and have well-described methodologies and clear findings. Findings- The review showed that TAM is still recognized as the right model for quantitative based information management research, and to a lesser extent qualitative information management research and desk studies. However, while some researchers concluded that the TAM is relevant in determining and assessing users' behaviour regarding technology usage with respect to time, others have criticised the TAM as too limited in the areas of theoretical assumptions and practical effectiveness. These critics have concluded that the model lacks the necessary attributes as a good theory for information system research.

Conclusion- In essence, the conflicting views create inconclusiveness about usage of TAM as a theoretical model. Such inconclusiveness calls for further research, and such research should set clear boundaries with respect to measurement of the issues, sampling procedures, and the analytical procedures.
\end{abstract}

Keywords: Technology acceptance model, users' behavioural, information management, intention to use, perceived usefulness. JEL Codes: D83, L15, M15

\section{INTRODUCTION}

Information is a vital organisational resource since it plays an important role in the achievement of organisational objectives. The importance of information as an organizational resource has been identified by many studies (Abdul Kargbo, 2005; Akotia, 2003; Robertson, 2005). Henczel (2000) also indicates that information provides the relevant intelligence that enables the right thing to be done at the right time, and it is widely recognized as a valuable business resource that plays an ever increasing and important part in running a business effectively. However, as opined by Robertson (2005), in order for the information to be useful and provide the needed knowledge, it has to be managed. According to Robinson, there is enough evidence to explain that the degree of success enjoyed by an organization and its members depends largely on how well information is managed. In this respect, Wang (2011) argued that organizations need to treat information management as an imperative organizational activity that should be linked to the mission, strategy and goals of organisations. 
Robertson (2005) explains that information management is a systematic process of collecting data from one or more sources, organizing, processing it into information, storing, and distributing the information to one or more users to help accomplish the organisational goals. As furthered by Akortsu and Abor (2011), it is the systematic and responsible management of information that will contribute strategically to the achievement of organization's goals, by making sure that groups and individuals have efficient access to and make effective use of the information. According to Mensah and Adams, (2014), information management objectives, among others, include; providing accurate, timely and relevant information for organisations, processing information and distributing them to all users as efficiently as possible, and to disposing of records that are no longer needed in the organisation. These objectives can only be achieved through effective management. In view of this, effective information management is therefore a key issue in organizations and has attracted a lot of attention of both researchers and practitioners.

Many studies have been undertaken in the area of information management and these studies have employed various theories to explain the concept. Some of the theories are the resource based view theory, organizational information processing theory and technology acceptance model. The resource based view (RBV) theory examines the importance of organizational resources, including information, in achieving competitive advantage (Rothaermel, (2012). The organizational information processing theory explains three important constructs, which include information processing needs, information processing capability, and the fit between the two to obtain optimal performance (Daft \& Lengel, 1986). The model argues that organizations need quality information to cope with environmental uncertainty and improve their decision making (Hitt, Wu, \& Zhou, 2002). The technology acceptance model (TAM) explains why technology is used in information management research.

Technology Acceptance Model (TAM) is one of the models that have been used extensively in information management research. The TAM was proposed by Davis (1989) to explain the factors that influence the acceptance and use of technology. The model argues that technology usage is influenced by users' attitude which is also influenced by perceived usefulness and perceived ease of use. The perceived usefulness and perceived ease of use are further influenced by other external factors. Since its introduction, TAM has been reviewed, extended, criticized and examined by many studies in relation to its internal and external consistency.

There are different opinions regarding its relevance in contemporary studies in information management. As indicated by Ravi (2011) effective information management combines technological innovations and intelligent processes to deliver cost effective information compliance and data protection. This suggests that, using the information technology and other accessories in information management enhances efficiency in information delivery. The need to examine why and how technology is adopted in information management research and practices, which is explained by TAM, cannot be over emphasized.

In this paper, we reviewed some studies that have employed the TAM in the area of information management regarding its relevance with respect to information management research, and how it has been extended in relation to its main factors; perceived usefulness (PU) and perceived ease of use (PEOU). We also identified the different opinions that exist with regard to its usage and made a case for further studies. Subsequent sections of the paper focus on theoretical and conceptual discussion on information management and the methodology used. The last section is focused on the results and discussion and conclusion.

\section{THEORETICAL AND CONCEPTUAL DISCUSSION ON INFORMATION MANAGEMENT}

The available literature indicates that there are controversies regarding the title, content, and the processes involved in information management (Anand, Manz, and Glick, 1988). Different writers prefer different titles to refer to a systematic process of collecting information from one or more sources, organizing, storing, and distributing of that information to one or more audiences (Robertson, 2005). The literature shows that information is a multi-disciplinary concept. It combines skills and resources from many fields of study including economics, management, organizational theory, information systems, library and information science (Maceviciute \& Wilson, 2002). All these fields have significant influences on information management work and research.

The application of the concept, principles and theories of management are also useful in information management research, and information as a resource must be planned, organized, and controlled to ensure efficiency and effectiveness (Akortsu \& Abor, 2011). Organizational theories which are part of management are focused on the behaviour of individuals within the work group, the nature of the group, the development of structures between and within groups and the process of implementing change, and explaining how the various behaviours influence organisational effectiveness. As indicated by 
Basharat, Mahmood, and Bashir (2012) management is so crucial that it is needed in all organisational activities, including information management research.

In response to the controversies in the information management literature with respect to title, content and discipline, which have resulted in different definitions, this study adapted a definition from Akotia (2000), Abdul Kargbo (2005) and Robertson (2005) that information management comprises all related disciplines and processes for gathering, managing, disseminating, leveraging and disposing of all types of information assets within an organization. In essence, we argue that information management is the systematic, imaginative and responsible management of information in order to contribute strategically to the achievement of organizational goals, by ensuring that groups and individuals have efficient access to and make effective use of the information.

Technically, information management includes all systems and process such as web content management, document management, records management, digital asset management, learning management systems, enterprise search, and all other activities, in connection with the technical infrastructure that is used to support the information management programmes. This elaboration is derived from the views of Adams (2006) that information management provides accurate, timely and complete information for effective decision making in the management and operation of an organisation (Adams, 2006), and Mensah and Adams (2014) that it provides information and records at the lowest possible cost. Other views that can be elicited in support of the elaboration are those by Read-Smith, Ginn and Kallaus (2002) that information management seeks to render maximum service to the user of the records and dispose of records that are no longer needed in the organization.

In addition to these objectives information management has the objective of processing recorded information and distributing them to all users as efficiently as possible (Robertson, 2005). In order for the objectives of information management to be attained, the technology that is used must be acceptable to the relevant stakeholders. According to Ogbomo and Ogbomo (2008), technology has played and continues to play an important role in managing information in the areas of, storage, processing and distribution. In their opinion, many contributions have been made with respect to information management research and one model that has been used extensively is the Technology Acceptance Model (TAM). The technology acceptance model (TAM), based on the Theory of Reasoned Action (TRA) was originated by Davis (1989) as part of his doctoral thesis (Shlh-Chlh, Shlng-Han, \& Chlen-Yi, 2011). The model looks at the factors that influence the acceptance of technology by an individual or a group. It examines the variables that are possible antecedents of managerial beliefs, attitudes, and use of information technology.

The model asserts that perceived usefulness and perceived ease of use determine an individual's intention to use a technology with the intention to use serving as a mediator of actual technology use (Chuttur, 2009). The model shows how individuals come to accept and use a technology, and it suggests that when users are presented with a new technology, a number of factors influence their decision about how and when they will use it. Among these factors are; the perceived usefulness and perceived ease-of-use as shown in Figure 1.

Figure 1: Technology Acceptance Model

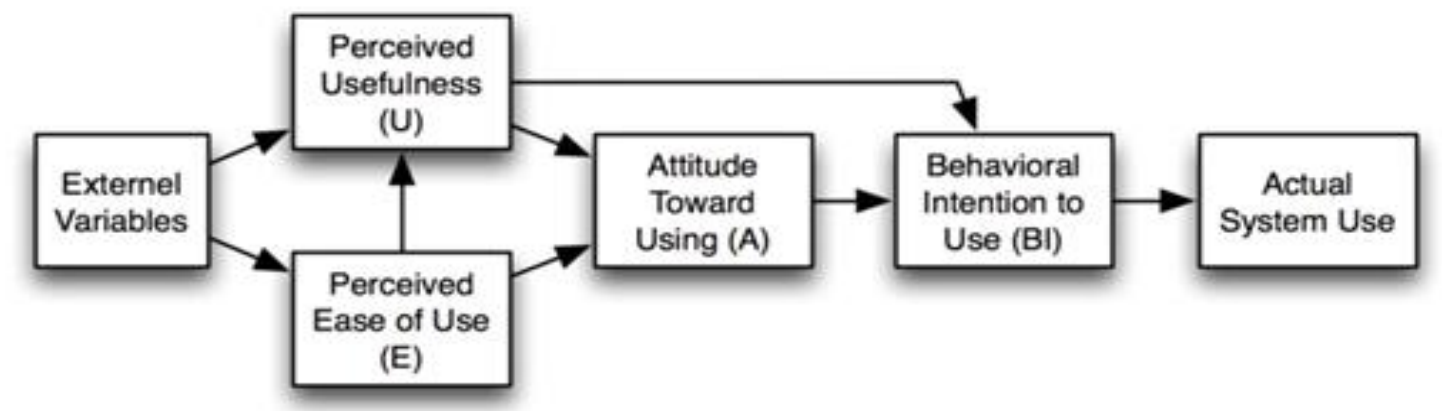

Source: Davis, F. D. (1989). "Perceived usefulness, perceived ease of use, and user acceptance of information technology." MIS Quarterly, 13(3), 319-340.

The perceived usefulness examines the degree to which a person believes that using a particular technology will enhance his or her job performance. Venkatesh and Davis (2000) explain that the perceived ease of use, on the other hand, examines the degree to which a person believes that using a particular technology would require minimal effort. The model stresses that the perceived ease of use and usefulness are further influenced by external factors. There are however, different opinions 
regarding these external factors and this review identifies the differences and how they influence the model (Legris, Ingham, \& Collerette, 2003). The Technology Acceptance Model has been studied by many researchers such as Dishaw and Strong (1999); Pijpers (2001); Koufaris (2002) and Averweg (2008). Venkatesh and Davis (2000) developed a theoretical extension of the TAM that explains perceived usefulness and usage intentions in terms of social influence and cognitive instrumental processes. They identified that there is an interactive effect between job relevance and output quality in determining perceived usefulness. Pijpers (2001) also used the model to examine the factors influencing managerial beliefs, attitudes and use of information technology in typical European-based companies. Pijpers identified such external variables as demographics, managerial and information technology knowledge, personality of the manager, company characteristics, and characteristics of the information technology, which were not identified by Davis (1986). The TAM like other theories is not without criticism. Studies such as those by Chuttur (2009) and Shroff, Deneen and Ng (2011) have criticised the model to be limited in the area of theoretical assumption and practical effectiveness and therefore lacks the necassary attributes as a good theory for information management research.

Notwithstanding these criticisms, many researchers including Malhotra and Galletta (1999), Tan and Chung (2005), Kulviwat, Bruner II, Kumar, Nasco and Clark (2007), Park (2009), Shlh-Chlh, Shlng-Han and Chlen-Yi (2011), Al-Adwan, Al-Adwan and Smedley(2013), Chiome (2013) and Sharma and Chandal (2013) agree that TAM is the right theory for information management research.

\section{METHODOLOGY}

The contents of this paper were derived from a desk based approach which was employed to examine articles that have used the TAM in information management research. Search engines such as Google scholar, yahoo search, and Answers. com were used to search through internationally renowned journals like Emerald, Science direct, IJRIC, South African Journal of Information Management, and other web sites for articles published from 1999 to 2016. In all 60 articles were consulted but 22 were selected. The 22 articles comprised those that used TAM in empirical studies, and those that had well-described methodologies and clear findings (Legris, Ingham, \& Collerette, 2003). The articles reviewed were presented in a tabular form and the tables were grouped into four categories based on quantitative field studies using parametric procedure, nonparametric procedure, qualitative field studies and desk based studies. Specifically the review identified the author (s) and the year, the topic, purpose, sample size, statistical techniques used and the study results.

\section{RESULTS AND DISCUSSION}

This section is focused on the discussion and implications of the various studies that have used the TAM. The summary of the categories are shown in Table 1.

Table 1: Summary of the Methodology/Procedure Used in the Articles

\begin{tabular}{|l|c|c|}
\hline Methodology Used & No of Articles & Percentages (\%) \\
\hline Quantitative, Parametric Procedure & 14 & 64 \\
\hline Quantitative, Non Parametric Procedure & 2 & 9 \\
\hline Qualitative Field Studies & 2 & 9 \\
\hline Desk Based Studies & 4 & 18 \\
\hline Total & 22 & 100 \\
\hline
\end{tabular}

The table shows the number of studies that have used the TAM and the procedure or methodology used. It is evident from the table that most of the articles employed a quantitative with parametric procedure, an indication that parametric quantitative procedures predominates information management research.

The review in each of these categories was presented in a table form followed by a brief discussion. The studies were arranged thematically and chronologically and for each study, the review provides the title of the paper, the authors and year of publication, objective of the study, sample size, statistical technique used, and the results of the study.

Table 2: Researches Based on Parametric Quantitative Procedures

\begin{tabular}{|c|c|c|c|c|c|c|}
\hline No & Author(s) and Year & Topic & Objective(s) & $\begin{array}{l}\text { Methodology } \\
\text { Statistical Technique }\end{array}$ & $\begin{array}{l}\text { Sample Size and the } \\
\text { Area of Study }\end{array}$ & Findings/Results \\
\hline & $\begin{array}{l}\text { Malhotra and } \\
\text { Galletta (1999) }\end{array}$ & $\begin{array}{l}\text { Extending the } \\
\text { TAM to Account }\end{array}$ & $\begin{array}{l}\text { Examined the } \\
\text { effect of social } \\
\text { influence in }\end{array}$ & $\begin{array}{l}\text { Factor analysis and } \\
\text { correlation -were }\end{array}$ & $\begin{array}{l}\text { Survey method } \\
\text { was adopted and }\end{array}$ & $\begin{array}{l}\text { TAM has emerged as one of } \\
\text { the influential models used in } \\
\text { IS research. }\end{array}$ \\
\hline
\end{tabular}




\begin{tabular}{|c|c|c|c|c|c|c|}
\hline 1. & . & $\begin{array}{l}\text { for Social } \\
\text { Influence }\end{array}$ & $\begin{array}{l}\text { determining the } \\
\text { acceptance and } \\
\text { usage of new IS. }\end{array}$ & $\begin{array}{l}\text { used to analyze the } \\
\text { data. }\end{array}$ & $\begin{array}{l}\text { a_sample size of } \\
239 \text { was used. }\end{array}$ & $\begin{array}{l}\text { Social influence plays a critical } \\
\text { role in IS acceptance and } \\
\text { usage. } \\
\text { Users' education and } \\
\text { involvement in the system } \\
\text { decision making can improve } \\
\text { acceptance and usage of new } \\
\text { system. }\end{array}$ \\
\hline 2 & $\begin{array}{l}\text { Venkatesh and } \\
\text { Davis (2000) }\end{array}$ & $\begin{array}{l}\text { A Theoretical } \\
\text { Extension of the } \\
\text { Technology } \\
\text { Acceptance } \\
\text { Model: Four } \\
\text { Longitudinal } \\
\text { Field Studies }\end{array}$ & $\begin{array}{l}\text { Developing a } \\
\text { theoretical } \\
\text { extension of the } \\
\text { TAM that } \\
\text { explains PU and } \\
\text { usage intentions } \\
\text { in terms of social } \\
\text { influence and } \\
\text { cognitive } \\
\text { instrumental } \\
\text { processes. }\end{array}$ & $\begin{array}{l}\text { Correlation } \\
\text { technique was used } \\
\text { for the analysis. }\end{array}$ & $\begin{array}{l}200 \text { employees } \\
\text { were sampled for } \\
\text { the study. }\end{array}$ & $\begin{array}{l}\text { It emerged that there is } \\
\text { interactive effect between } \\
\text { job relevance and output } \\
\text { quality in determining } \\
\text { perceived usefulness. }\end{array}$ \\
\hline 3. & Pijpers(2001) & $\begin{array}{l}\text { Understanding } \\
\text { senior executives' } \\
\text { use of IT and the } \\
\text { Internet }\end{array}$ & $\begin{array}{l}\text { Examined the } \\
\text { factors influencing } \\
\text { managerial beliefs, } \\
\text { attitudes and use of } \\
\text { information } \\
\text { technology. }\end{array}$ & $\begin{array}{l}\text { A cross-sectional } \\
\text { field survey and } \\
\text { Structural equation } \\
\text { model were used. }\end{array}$ & $\begin{array}{l}\text { European-based } \\
\text { companies } \\
\text { Philips Electronics, } \\
\text { The Netherlands }\end{array}$ & $\begin{array}{l}\text { External variables such as } \\
\text { demographics, managerial, } \\
\text { knowledge in IT, company and } \\
\text { IT characteristics have effects } \\
\text { on PU and PEOU. }\end{array}$ \\
\hline 4. & $\begin{array}{l}\text { Amoako-Gyampah } \\
\text { Salam(2004) }\end{array}$ & $\begin{array}{l}\text { An extension of } \\
\text { the TAM in an } \\
\text { ERP } \\
\text { implementation } \\
\text { environment }\end{array}$ & $\begin{array}{l}\text { Evaluated the } \\
\text { impact of the } \\
\text { belief construct, } \\
\text { training and } \\
\text { communication } \\
\text { on PU and PEOU }\end{array}$ & $\begin{array}{l}\text { Factor analysis and } \\
\text { Structural equation } \\
\text { model were adopted. }\end{array}$ & $\begin{array}{l}\text { A survey of } 571 \\
\text { employees from } \\
\text { selected health } \\
\text { institutions in } \\
\text { selected regions of } \\
\text { USA were used for } \\
\text { the study }\end{array}$ & $\begin{array}{l}\text { TAM was extended by adding } \\
\text { a belief construct (shared } \\
\text { belief) and two external } \\
\text { variables (training and } \\
\text { communication) }\end{array}$ \\
\hline 5. & $\begin{array}{l}\text { Tan \& Chung, } \\
\text { (2005) }\end{array}$ & $\begin{array}{l}\text { Validating the } \\
\text { Extended TAM } \\
\text { Perceived } \\
\text { Playfulness in } \\
\text { the Context of } \\
\text { information- } \\
\text { searching } \\
\text { Websites }\end{array}$ & $\begin{array}{l}\text { Explored the } \\
\text { influence of the } \\
\text { intrinsic factor } \\
\text { "perceived } \\
\text { playfulness", in } \\
\text { the context of } \\
\text { information } \\
\text { searching sites } \\
\text { on the Internet }\end{array}$ & $\begin{array}{l}\text { Partial least square } \\
\text { technique was used } \\
\text { for the data analysis }\end{array}$ & $\begin{array}{l}\text { One hundred and } \\
\text { fifty four (154) } \\
\text { questionnaires } \\
\text { from students } \\
\text { attending IS } \\
\text { courses at a } \\
\text { university in New } \\
\text { Zealand were } \\
\text { used for statistical } \\
\text { analysis. }\end{array}$ & $\begin{array}{l}\text { The results indicate that PU } \\
\text { had a stronger effect on } \\
\text { Attitude toward Using than } \\
\text { PEOU. }\end{array}$ \\
\hline 6. & $\begin{array}{l}\text { Kulviwat, Bruner } \\
\text { II, Kumar, Nasco, } \\
\text { \& Clark(2007) }\end{array}$ & $\begin{array}{l}\text { Toward a } \\
\text { Unified Theory } \\
\text { of Consumer } \\
\text { Acceptance } \\
\text { Technology }\end{array}$ & $\begin{array}{l}\text { Assessed the role } \\
\text { of the PAD } \\
\text { paradigm of } \\
\text { affect in the } \\
\text { TAM. }\end{array}$ & $\begin{array}{l}\text { Structural Equation } \\
\text { Model (SEM) was } \\
\text { used. }\end{array}$ & $\begin{array}{l}\text { Data were } \\
\text { collected from } \\
260 \\
\text { undergraduate } \\
\text { students at a } \\
\text { large Midwestern } \\
\text { US } \\
\text { University. } \\
\end{array}$ & $\begin{array}{l}\text { The study result support the } \\
\text { fact that PEOU has a positive } \\
\text { influence on actual use of a } \\
\text { system. } \\
\text { That pleasure and arousal } \\
\text { have positive influence on } \\
\text { attitude. }\end{array}$ \\
\hline 7. & $\begin{array}{l}\text { Bertrand \& } \\
\text { Bouchard (2008) }\end{array}$ & $\begin{array}{l}\text { Applying the TAM } \\
\text { to VR with people } \\
\text { who are } \\
\text { favorable to its } \\
\text { use. }\end{array}$ & $\begin{array}{l}\text { Determined } \\
\text { how the TAM } \\
\text { applies to the } \\
\text { use of virtual } \\
\text { reality in clinical } \\
\text { settings }\end{array}$ & $\begin{array}{l}\text { Structural equation } \\
\text { modeling, ANOVA and } \\
\text { correlation were used }\end{array}$ & $\begin{array}{l}\text { Data were } \\
\text { collected from } \\
141 \text { adults who } \\
\text { are interested in } \\
\text { using this VR } \\
\text { from Canada, } \\
\text { USA, Spain, } \\
\text { France, Israel, } \\
\text { Italy, UK, } \\
\text { Australia, } \\
\text { Germany, Greece, } \\
\text { Japan, Korea, }\end{array}$ & $\begin{array}{l}\text { Intention to Use VR is } \\
\text { predicted only by Perceived } \\
\text { Usefulness. }\end{array}$ \\
\hline
\end{tabular}




\begin{tabular}{|c|c|c|c|c|c|c|}
\hline & & & & & $\begin{array}{l}\text { Luxembourg, } \\
\text { Scotland and } \\
\text { Sweden }\end{array}$ & \\
\hline 8. & $\begin{array}{l}\text { Venkatesh \& } \\
\text { Bala(2008) }\end{array}$ & $\begin{array}{l}\text { TAM and a } \\
\text { Research } \\
\text { Agenda on } \\
\text { Interventions }\end{array}$ & $\begin{array}{l}\text { Identified the } \\
\text { gap in the } \\
\text { literature, draw } \\
\text { from the vast } \\
\text { body of } \\
\text { research on the } \\
\text { TAM, on the } \\
\text { determinants of } \\
\text { PU and PEOU. }\end{array}$ & $\begin{array}{l}\text { Partial Least } \\
\text { Squares (PLS), a } \\
\text { component-based } \\
\text { structural equation } \\
\text { modeling technique } \\
\text { was used. }\end{array}$ & $\begin{array}{l}\text { Sample size of } \\
154 \text { from four } \\
\text { organizations } \\
\text { over a 5-month } \\
\text { period with four } \\
\text { points of } \\
\text { measurements. }\end{array}$ & $\begin{array}{l}\text { That the determinants of PU } \\
\text { will not influence PEOU and } \\
\text { vice versa. } \\
\text { There is potential } \\
\text { relationship between } \\
\text { interventions and PU and } \\
\text { PEOU which offers an } \\
\text { important future research } \\
\text { direction. } \\
\text { Experience is an important } \\
\text { moderating variable in } \\
\text { IT/system adoption and } \\
\text { usage. }\end{array}$ \\
\hline 9. & Park (2009) & $\begin{array}{l}\text { An analysis of the } \\
\text { TAM in } \\
\text { understanding } \\
\text { university } \\
\text { students BI to use } \\
\text { e-learning }\end{array}$ & $\begin{array}{l}\text { Analyze the } \\
\text { relationship of } \\
\text { learners' intention } \\
\text { to use e-learning } \\
\text { with selected } \\
\text { variables such as } \\
\text { attitude, PU, } \\
\text { PEOU, self-efficac } \\
\text { and accessibility. }\end{array}$ & $\begin{array}{l}\text { Structural equation } \\
\text { model was employed }\end{array}$ & $\begin{array}{l}\text { In all } 628 \text { of Konkuk } \\
\text { University students } \\
\text { of South Korea were } \\
\text { sampled for the } \\
\text { study. }\end{array}$ & $\begin{array}{l}\text { TAM is good model to } \\
\text { understand users' acceptance } \\
\text { of e-learning. } \\
\text { Self-efficacy, subjective norms } \\
\text { and system accessibility are } \\
\text { important constructs that } \\
\text { affect both BI and attitude. }\end{array}$ \\
\hline 10. & Çelik \& Yılmaz, 2011 & $\begin{array}{l}\text { Extending the } \\
\text { TAM for } \\
\text { adoption of e- } \\
\text { shopping by } \\
\text { consumers in } \\
\text { Turkey. }\end{array}$ & $\begin{array}{l}\text { Explained } \\
\text { consumer } \\
\text { acceptance of } \\
\text { e-shopping by } \\
\text { means of an } \\
\text { extended } \\
\text { model based on } \\
\text { TAM. }\end{array}$ & $\begin{array}{l}\text { Structural equation } \\
\text { model was used to } \\
\text { analyse these data. }\end{array}$ & $\begin{array}{l}\text { Electronic-survey } \\
\text { was used to } \\
\text { collect the data } \\
\text { from } 606 \text { internet } \\
\text { users in Turkey. }\end{array}$ & $\begin{array}{l}\text { There is the need for further } \\
\text { theoretical and experimental } \\
\text { studies in order to expand the } \\
\text { classical TAM. } \\
\text { TAM must be revised in line } \\
\text { with new developments in } \\
\text { information technologies. }\end{array}$ \\
\hline 11. & $\begin{array}{l}\text { Hanadi, Samer, \& } \\
\text { Hasan (2012) }\end{array}$ & $\begin{array}{l}\text { IT acceptance } \\
\text { by University } \\
\text { lecturers. }\end{array}$ & $\begin{array}{l}\text { Explored how } \\
\text { PU, PEOU, PC, } \\
\text { computing and } \\
\text { management } \\
\text { supports may } \\
\text { influence IT } \\
\text { acceptance. }\end{array}$ & $\begin{array}{l}\text { Regression Analysis } \\
\text { was employed. }\end{array}$ & $\begin{array}{l}\text { A purposive } \\
\text { sampling } \\
\text { technique was } \\
\text { used to select } 156 \\
\text { Lecturers within } \\
\text { the applied } \\
\text { science private } \\
\text { university, Jordan. }\end{array}$ & $\begin{array}{l}\text { PU has no influence on IT } \\
\text { acceptance. } \\
\text { But PEOU, PC, computing and } \\
\text { management supports } \\
\text { influence IT acceptance. }\end{array}$ \\
\hline 12. & Punnoose (2012) & $\begin{array}{l}\text { Determinants } \\
\text { of Intention to } \\
\text { Use eLearning } \\
\text { Bangkok, } \\
\text { Thailand. }\end{array}$ & $\begin{array}{l}\text { Determined the } \\
\text { predominant } \\
\text { factors that } \\
\text { influence } \\
\text { students } \\
\text { intention to use } \\
\text { e-Learning in } \\
\text { the future }\end{array}$ & $\begin{array}{l}\text { The Structural } \\
\text { Equation Modeling } \\
\text { (SEM) analysis was } \\
\text { used to answer the } \\
\text { research questions. }\end{array}$ & $\begin{array}{l}\text { A total of } 249 \\
\text { questionnaires } \\
\text { were collected. }\end{array}$ & $\begin{array}{l}\text { Only three out of the five } \\
\text { personality trait } \\
\text { extraversion, } \\
\text { conscientiousness, and } \\
\text { neuroticism variables turned } \\
\text { out to be significant in the } \\
\text { final model. }\end{array}$ \\
\hline 13. & $\begin{array}{l}\text { Al-Adwan, Al- } \\
\text { Adwan, \& Smedley } \\
\text { (2013) }\end{array}$ & $\begin{array}{l}\text { Exploring } \\
\text { students' } \\
\text { acceptance of } \\
\text { e-learning using } \\
\text { TAM in } \\
\text { Jordanian } \\
\text { universities. }\end{array}$ & $\begin{array}{l}\text { Examined the } \\
\text { factors that } \\
\text { influence } \\
\text { students' } \\
\text { acceptance of e- } \\
\text { learning and to } \\
\text { identify the } \\
\text { important factors } \\
\text { that would } \\
\text { contribute to its } \\
\text { successful use. }\end{array}$ & $\begin{array}{l}\text { Case study and } \\
\text { quantitative } \\
\text { methods of data } \\
\text { collection were } \\
\text { adopted. } \\
\text { A regression } \\
\text { analysis was } \\
\text { conducted to test } \\
\text { the hypotheses. }\end{array}$ & $\begin{array}{l}\text { Data were } \\
\text { collected from } \\
107 \text { students of } \\
\text { the Foreign } \\
\text { language } \\
\text { department of } \\
\text { Applied Science } \\
\text { University. }\end{array}$ & $\begin{array}{l}\text { TAM is a useful theoretical } \\
\text { base to predict and } \\
\text { understand users' intentions } \\
\text { to use a system. PU had no } \\
\text { significant influence on } \\
\text { students' attitude. } \\
\text { PEOU significantly } \\
\text { Influenced both attitude and } \\
\text { PU. }\end{array}$ \\
\hline
\end{tabular}




\begin{tabular}{|c|c|c|c|c|c|c|}
\hline 14. & $\begin{array}{l}\text { Sharma \& } \\
\text { Chandal (2013) }\end{array}$ & $\begin{array}{l}\text { TAM for use of } \\
\text { learning } \\
\text { through } \\
\text { websites among } \\
\text { students in } \\
\text { Oman. }\end{array}$ & $\begin{array}{l}\text { Identified the } \\
\text { factors that } \\
\text { influence the } \\
\text { students' } \\
\text { learning through } \\
\text { website. }\end{array}$ & $\begin{array}{l}\text { Parametric } \\
\text { statistical } \\
\text { techniques were } \\
\text { used to test the } \\
\text { hypotheses. } \\
\text { Factor analysis was } \\
\text { also used to identify } \\
\text { the predictors. }\end{array}$ & $\begin{array}{l}\text { Survey method } \\
\text { was employed. } \\
\text { Questionnaires } \\
\text { were randomly } \\
\text { distributed to } 100 \\
\text { students. }\end{array}$ & $\begin{array}{l}\text { The study validates the } \\
\text { previous TAM results. } \\
\text { PU and PEOU have positive } \\
\text { effects on BI. Quality and } \\
\text { self-efficacy of the system } \\
\text { have positive relationship } \\
\text { with the BI. } \\
\text { Attitude and BI relate } \\
\text { positively. } \\
\text { TAM is a powerful and } \\
\text { reliable predictive model } \\
\text { that may be used in various } \\
\text { contexts. }\end{array}$ \\
\hline
\end{tabular}

In addition to the specific findings and conclusions per study, the contents in the table show that 14 out of the 22 articles reviewed used parametric quantitative procedure. This clearly shows the popularity and acceptance of the quantitative methods and parametric procedures in information management research over the qualitative and the non-parametric procedure. The table also indicates that the articles selected for the review cut across the globe, from both developed and developing countries. It can also be seen from the table that the articles reviewed cover all spheres of human endeavour, from industry to academic.

The overriding objective of all these studies was to determine the validity and relevance of the TAM with respect to information management research. The results in table clearly indicate that perceived usefulness (PU) and perceived ease of use (PEOU) have positive effects on behaviour intention (BI) to use the technology. It was also identified that PU had no significant influence on attitude, however, PEOU significantly influenced both attitude and PU. The findings from the review also show that TAM is a useful theoretical base to predict and understand users' intentions to use a technology. Lastly, it was identified that TAM has emerged as one of the influential models used in information management research, and has established that social influence plays a critical role in technology acceptance and usage. The model has also been eastablished that users' education and involvement in the technology decision making can improve on the acceptance and usage of new technology.

As part of the review, we also examined articles that used non-parametric quantitative procedures and the results are shown in the Table 3.

Table 3: Research based on Non-Parametric Quantitative Procedures

\begin{tabular}{|c|c|c|c|c|c|c|}
\hline No & $\begin{array}{l}\text { Author(s) } \\
\text { and Year }\end{array}$ & Topic & Objective(s) & $\begin{array}{l}\text { Methodology } \\
\text { Statistical Technique }\end{array}$ & $\begin{array}{l}\text { Sample Size and } \\
\text { the Area of Study }\end{array}$ & Findings/Results \\
\hline 1. & $\begin{array}{l}\text { Averweg, } \\
\text { (2008) }\end{array}$ & $\begin{array}{l}\text { IT acceptance in } \\
\text { South Africa: An } \\
\text { investigation of PU, } \\
\text { PEOU, and actual } \\
\text { system use } \\
\text { constructs. }\end{array}$ & $\begin{array}{l}\text { Examined the } \\
\text { correlation between } \\
\text { PU, PEOU and actua } \\
\text { use. }\end{array}$ & $\begin{array}{l}\text { Spearman rank-order } \\
\text { correlation analysis } \\
\text { was used. }\end{array}$ & $\begin{array}{l}\text { A survey of } 31 \\
\text { organizations in } \\
\text { KwaZulu/Natal, } \\
\text { a region in } \\
\text { South Africa. }\end{array}$ & $\begin{array}{l}\text { There was a lower } \\
\text { correlation for PU than } \\
\text { PEOU which contradicts } \\
\text { Davis claims that PU over } \\
\text { rides PEOU. }\end{array}$ \\
\hline 2 & $\begin{array}{l}\text { Shroff, } \\
\text { Deneen, \& } \\
\text { Ng, (2011) }\end{array}$ & $\begin{array}{l}\text { Analysis of the TAM } \\
\text { in } \\
\text { examining students' } \\
\text { behavioural } \\
\text { intention to use an } \\
\text { e portfolio } \\
\text { system. }\end{array}$ & $\begin{array}{l}\text { Examined } \\
\text { students' BI to } \\
\text { use an e portfolio } \\
\text { system, to explain } \\
\text { how students use } \\
\text { and appropriate it } \\
\text { within the specific } \\
\text { framework of a } \\
\text { course. }\end{array}$ & $\begin{array}{l}\text { Correlation and Chi- } \\
\text { square were used to } \\
\text { analyse the data }\end{array}$ & $\begin{array}{l}\text { Questionnaires } \\
\text { were } \\
\text { Administered to } \\
169 \text { students } \\
\text { for the study. }\end{array}$ & $\begin{array}{l}\text { There was no significant } \\
\text { relationship between } \\
\text { PU, ATU and BIU to use } \\
\text { the e-portfolio system. } \\
\text { The result was } \\
\text { consistent with other } \\
\text { findings which suggest } \\
\text { that the role of ATU in } \\
\text { the TAM has been } \\
\text { inconclusive. }\end{array}$ \\
\hline
\end{tabular}

The results in Table 3 show that only two articles used non- parametric quantitative procedures, which means that there is low patronage with respect to the non-parametric procedure in information management research. The findings in the two articles show that there is a weak correlation between perceive usefulness (PU) and perceive ease of use (PEOU), which contradicts Davis (1986) claims that PU over rides PEOU. It was also identified that there is no significant relationship between PU, attitude toward use (ATU) and behaviour intention to use (BIU) with respect to usage of the e-portfolio system.

The result was consistent with other findings which suggest that the role of ATU in the TAM has been inconclusive. 
We reviewed two researches that used a qualitative approach in studying the TAM with respect to information management research, and the key issues are summarized in Table 4.

Table 4: Qualitative Field Studies on TAM

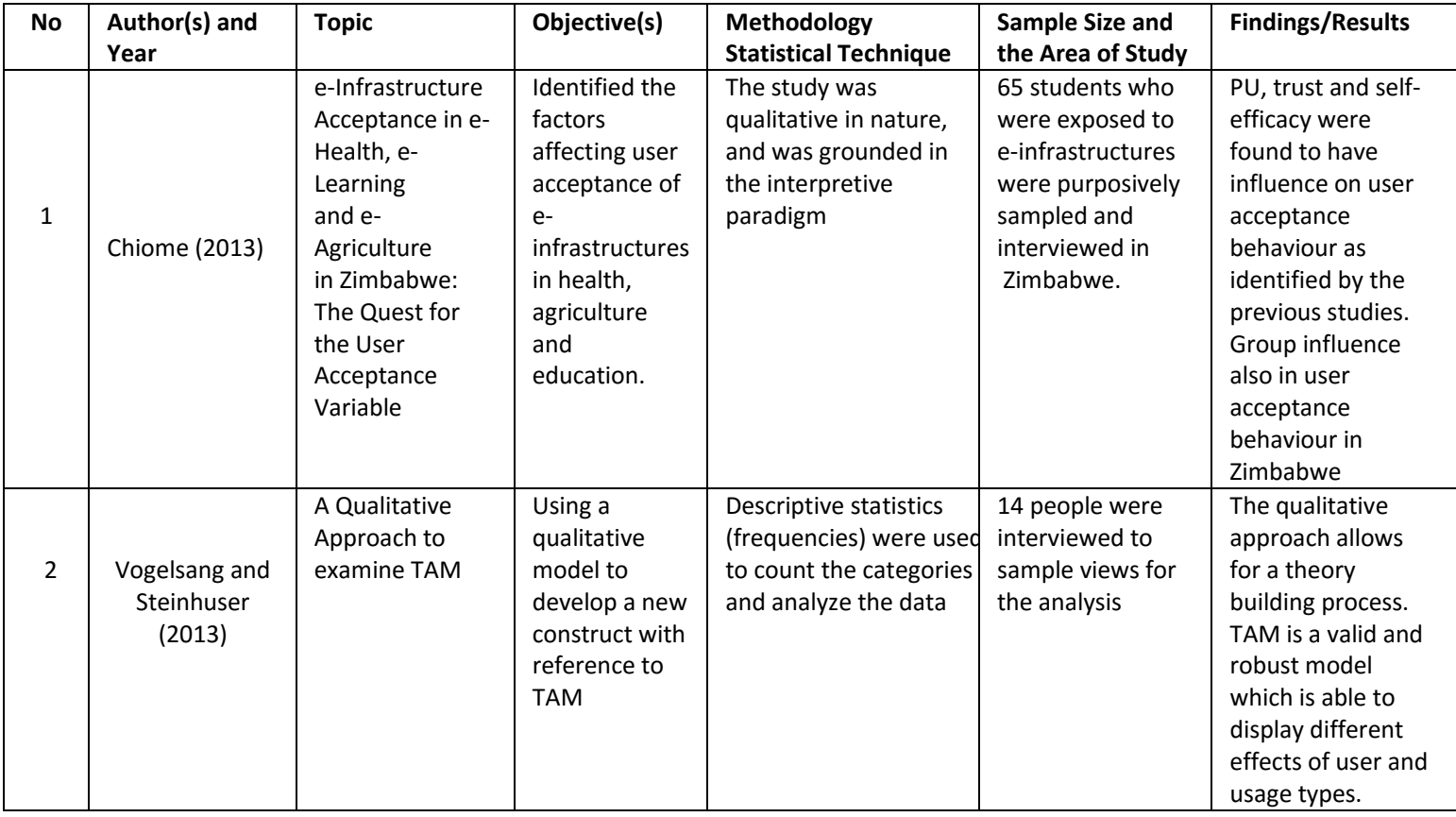

Two researchers used a qualitative approach in studying the model. The result indicates that PU, trust and self-efficacy were found to play important roles in user acceptance behaviour as identified by the previous studies. The review identified TAM as a valid and robust model which is able to display different effects of user and usage types and that qualitative approach allows for a theory building process.

A few more studies were based on desk reviews, and the results are shown in Table 5.

Table 5: Desk Based Studies on TAM

\begin{tabular}{|c|c|c|c|c|c|c|}
\hline No & $\begin{array}{l}\text { Author(s) } \\
\text { and Year }\end{array}$ & Topic & Objective(s) & $\begin{array}{l}\text { Methodology } \\
\text { Statistical } \\
\text { Technique }\end{array}$ & $\begin{array}{l}\text { Sample Size and } \\
\text { the Area of } \\
\text { Study }\end{array}$ & Findings/Results \\
\hline 1. & $\begin{array}{l}\text { King \& He, } \\
(2006)\end{array}$ & $\begin{array}{l}\text { A meta- } \\
\text { analysis of } \\
\text { the TAM }\end{array}$ & $\begin{array}{l}\text { Examined the } \\
\text { conditions } \\
\text { under which } \\
\text { TAM may have } \\
\text { different } \\
\text { effects. }\end{array}$ & $\begin{array}{l}\text { Correlation was } \\
\text { used to analyze the } \\
\text { data }\end{array}$ & $\begin{array}{l}\text { Meta-analysis, } \\
88 \text { published } \\
\text { studies were } \\
\text { reviewed }\end{array}$ & $\begin{array}{l}\text { Four major categories of modification were } \\
\text { identified; } \\
\text { - } \quad \text { external precursors (prior factors) } \\
\text { - } \quad \text { factors suggested by other theories } \\
\text { - } \quad \text { contextual factors such as gender and } \\
\text { - } \quad \text { consequence measures such as } \\
\text { attitude. }\end{array}$ \\
\hline 2. & $\begin{array}{l}\text { Chuttur } \\
\text { (2009) }\end{array}$ & $\begin{array}{l}\text { Overview of } \\
\text { the TAM: } \\
\text { Origins, } \\
\text { Developmen } \\
\text { ts and } \\
\text { Future } \\
\text { Directions }\end{array}$ & $\begin{array}{l}\text { Provided the } \\
\text { historical } \\
\text { overview of the } \\
\text { TAM, its } \\
\text { application, } \\
\text { extension and } \\
\text { limitations }\end{array}$ & Literature review & $\begin{array}{l}\text { Davis original } \\
\text { work, TAM and } \\
\text { TAM2 and TRA } \\
\text { were reviewed }\end{array}$ & $\begin{array}{l}\text { The researchers have different opinions on } \\
\text { the theoretical assumptions and practical } \\
\text { effectiveness of the TAM. } \\
\text { That the model lacks the necessary } \\
\text { features that can make it a good theory for } \\
\text { information system research. }\end{array}$ \\
\hline 3 & $\begin{array}{l}\text { Shlh-Chlh, } \\
\text { Shlng-Han, }\end{array}$ & $\begin{array}{l}\text { Recent } \\
\text { related } \\
\text { research in }\end{array}$ & $\begin{array}{l}\text { Discussed the } \\
\text { related } \\
\text { studies in }\end{array}$ & $\begin{array}{l}\text { Literature } \\
\text { review }\end{array}$ & $\begin{array}{l}24 \text { studies were } \\
\text { reviewed }\end{array}$ & TAM is the right theory for IM research. \\
\hline
\end{tabular}




\begin{tabular}{|l|l|l|l|l|l|l|}
\hline Chlen-Yi, & $\begin{array}{l}\text { technology } \\
\text { acceptance } \\
\text { (2011) }\end{array}$ & $\begin{array}{l}\text { order to } \\
\text { clarify the } \\
\text { extension of } \\
\text { the } \\
\text { literature } \\
\text { review }\end{array}$ & $\begin{array}{l}\text { Technology } \\
\text { acceptance } \\
\text { model. }\end{array}$ & & & \\
\hline
\end{tabular}

The result indicates that researchers have different opinions on the theoretical assumptions and practical effectiveness of the TAM. While some argue that the model lacks the necessary features that can make it a good theory for information management research, others like Shlh-Chlh, Shlng-Han, \& Chlen-Yi, (2011) maintained that TAM is the right theory for information management research. In their view, TAM still stands out as one of the best theories to use in information management research since it leads to better prediction of acceptance and use of new information resources.

\section{CONCLUSIONS AND IMPLICATIONS}

The review identifies that the technology acceptance model has emerged as one of the influential models that is used to understand and predict users' acceptability, behavioural intention to use and actual use of a system. There are some competing claims by researchers. However, while some researchers concluded that the TAM is relevant in determining and assessing users' behaviour regarding technology usage with respect to time, others have criticised the TAM as too limited in the areas of theoretical assumptions and practical effectiveness. These critics have concluded that the model lacks the necessary attributes as a good theory for information system research.

In terms of specific phenomena, researchers like Venkatesh and Davis (2000) and Averweg (2008) disagree with Davis' (1986) original proposal and concluded that perceived ease of use has no influence on perceived usefulness. The review also shows that in some situations only one of the factors, either perceived usefulness or perceived ease of use influences behavioural intention to use a technology.

With respect to the external factors that influence perceived usefulness and perceived ase of use, many factors have been identified to play important roles. These include; self-efficacy, subjective norms, system accessibility, training and communication, demographic and managerial supports. It has emerged from the review that depending on the type of technology being introduced and the area of application, different factors may influence the acceptance, intention to use and actual use.

In essence, the conflicting views create inconclusiveness about usage of TAM as a theoretical model. Such inconclusiveness calls for further research, and such research should set clear boundaries with respect to measurement of the issues, sampling procedures, and the analytical procedures. Once there is consistence in the methodology we will have a sound basis for either accepting or rejecting TAM as a model for studying the influence perceived usefulness and perceived ease of use have on the behavioural intention to use and actual use.

\section{REFERENCES}

Akortsu, M. A., \& Abor, P. A. (2011). Financing public healthcare institutions in Ghana. Journal of Health Organisation and Management, 25 (2), 128-141.

Akotia, P. (2003). Public sector records systems in Ghana: Some lessons in development management. African Journal of Library Archives and Information Science, 13 (2).

Abdul Kargbo, J. (2005). Archives management in post-war Sierra Leone: Luxury or necessity? Journal of the Society of Archives, 26 (2).

Adams, M. (2006). Freedom of information and records management in Ghana. African Journal of Library Archives and Information Science, $16(1), 1-6$

Al-Adwan, A., Al-Adwan, A., \& Smedley, J. (2013). Exploring students acceptance of e-learning using Technology Acceptance Model in Jordanian universities. International Journal of Education and Development using Information and Communication Technology (IJEDICT), 9, (2), 4-18.

Amoako-Gyampah, K., \& Salam, A. F. (2004). An extension of the technology acceptance model in an ERP implementation environment. Information \& Management, (41) 731- 745. 
Anand, V., Manz, C. C., \& Glick, W. H. (1988). An organisational memory approach to information management. Academy of Managemet Review, 23 (4), 796-800.

Averweg, R. U. (2008). Information technology acceptance in South Africa: An investigation of perceived usefulness, perceived ease of use and actual system use construct. African Journal of Information Systems, 1, (1), Article 4.

Basharat, M., Mahmood, Z., \& Bashir, Z. (2012). Review of classical canagement theories . International Journal of Social Sciences and Education , 512-522.

Bertrand, M., \& Bouchard, S. (2008). Applying the technology acceptance mpdel to virtual reality among clinicians. Journal of Cyber Therapy and Rehabilitation; Virtual Reality Medical Institute, 1, 2.

Çelik, H. E., \& Yılmaz, V. (2011). extending the technology acceptance model for adoption of e shopping by consumers in Turkey. Journal of Electronic Commerce Research, 12, 2.

Chiome, C. (2013). e-Infrastructure acceptance in e-Health, e-Learning and e-Agriculture in Zimbabwe: The quest for the user acceptance variable. The 6th UbuntuNet Alliance annual conference (pp. 29-39). Harare, Zimbabwe: UbuntuNet Alliance.

Chuttur, M. (2009). Overview of the technology acceptance model: Origins, developments and future directions. Indiana University, USA . Sprouts: Working Papers on Information Systems, 9(37). http://sprouts.aisnet.org/9-37.

Daft, R. L., \& Lengel, R. H. (1986). Organisational information requirements, media richness and structural design. Management Science, Jstor., 32 (5), 554-571.

Davis, F. D. (1989). Perceived usefulness, perceived ease of use, and user acceptance of information technology. MIS Quart. 13(1), 319-339.

Davis, F. D. (1986). “Perceived usefulness, perceived ease of use, and user acceptance of information technology." MIS Quarterly, 13(3), 319-340.

Dishaw, M. T., \& Strong, D. M. (1999). Extending the technology acceptance model with task-technology fit constructs. Information \& Management, $9-21$.

Dorr, S., Walther, S., \& Eymann, T. (2013). Information systems success: A quantitative literature review and comparison . 11th International Conference on Wirtschaftinformatik, (pp. 1813 - 1827). Leipzig, Germany.

Hanadi, A. Z., Samer, B. M., \& Hasan, A.-Z. A. (2012). Information technology acceptance by university lecturers: Case Study at Applied. European Scientific Journal, (10) 8.

Henczel, S. (2000). The information audit as a first step towards. Brighton: Special Libraries Association.

Hitt, L. M., Wu, D. J., \& Zhou, X. (2002). Investment in enterprise resource planning: Business impact and productivity measures. Journal of Management Information Systems, 19 (1), 71-98.

King, W. R., \& He, J. (2006). A meta-analysis of the technology acceptance model. Information \& Management: Science Direct, (43) $740-755$.

Koufaris, M. (2002). Applying the technology acceptance model and flow theory to online consumer behaviour. Information Systems Research , 205.

Kulviwat, S., Bruner II, G. C., Kumar, A., Nasco, S. A., \& Clark, T. (2007). Toward a unified theory of consumer acceptance technology. Psychology \& Marketing; Wiley Periodicals, Inc., 24(12), 1059-1084.

Legris, P., Ingham, J., \& Collerette, P. (2003). Why do people use information technology: A critical review of the technology acceptance model. Information \& Management, 191-204.

Maceviciute, E., \& Wilson, T. D. (2002). The development of the information management research area. Information Research 7, 3.

Malhotra, Y., \& Galletta, D. F. (1999). Extending the Technology Acceptance Model to account for social influence: Theoretica bases and empirical validation. Proceeding of the 32nd Hawaii International Conference on System Science, (pp. 1-14). Hawaii.

Mensah, M., \& Adams, M. (2014). The nexus between corporate governance and records management in private and public hospitals in Ghana. Records Management Jounal, 24 (1), 32-55.

Ogbomo, J. A., \& Ogbmo, E. F. (2008). Importance of Information and Communication Technology in making a healty information society. Ethiope East Local Government Area of data state, Nigeria: Philosophy and practice.

Oluwule, D. O. (2016). Technology acceptance model as a predictor of using information system to acquire information literacy skills.https://www.semanticscholar.org/paper/An-assessment-of-the-changing-needs-of-information-Chikonzo-Bothma. 
Park, S. Y. (2009). An analysis of the technology acceptance model in understanding university students behavioural intention to use e-learning. Educational Technology and Society, 12 (3), 150-162.

Pijpers, G. (2001). An examination of factors influencing managerial beliefs, attitude and use of information technology. Guus Pijpers.

Punnoose, A. C. (2012). Determinants of Intention to Use eLearning Based on the Technology Acceptance Model. Journal of Information Technology Education: Research, 11.

Ravi, T. M. (2011). The path to information management Nirvana. Information Management Daily, 1(2), 1-7.

Read-Smith, J., Ginn, M. L., \& Kallaus, N. F. (2002). Records management (7 ${ }^{\text {th }}$ ed.). New York: Thompson Learning Inc: SouthWestern.

Robertson, J. (2005). Ten principles of effective information management: Step Two Design Limited. (http//.www.steptwo.com.au/papers/kmc_effectiveim/index.html).

Rothaermel, F. T. (2012). Strategic management: Concepts and cases. New York: MacGraw-Hill/Irwin.

Sharma, S. K., \& Chandal, J. K. (2013). Technology acceptance model for use of learing through websites among students in Oman. International Arab Journal of E-technology, 3, (1), 44 - 49.

Shlh-Chlh, C., Shlng-Han, L., \& Chlen-Yi, L. (2011). Recent related research in Technology Acceptance Model: A literature review. Australian Journal of Business and Management Research, 1 (9), 124-127.

Shroff, R. H., Deneen, C. C., \& Ng, E. M. (2011). Analysis of the Technology Acceptance Model in examining students' behavioural intention to use an e-portfolio system. Australasian Journal of Educational Technology, 27(4), 600-618.

Tan, F. B., \& Chung, J. (2005). Validating the Extended Technology Acceptance Model: Perceived playfulness in the context of information-searching websites. New Zealand: ACIS.

Vogelsang, K., Steinhuser, M., \& Hoppe, U. (2013). A qualitative approach to explain technology acceptance. Thirty fourth International Conference on Information Systems. University of Osnabrück.

Venkatesh, V., \& Bala, H. (2008). Technology Acceptance Model 3 and a research agenda on interventions. Decision Sciences Institute, 39 (2), 1-43

Venkatesh, V., \& Davis, F. D. (2000). A theoretical extension of the Technology Acceptance Model: Four longitudinal field studies. Management Science, 46, (2), 186-204.

Wang, W. T. (2011). Examining knowledge management during issue management: anagement Research Review, 34(4), 436-449. 